\title{
THE ANALYSIS OF THE CROSS-BORDER CORPORATE PROFIT's TAXATION
}

\author{
Rita Koroseczné Pavlin, Diána KoponiCsné GYöRKE \\ Kaposvár University, Faculty of Economic Science, H-7400 Kaposvár, Guba Sándor u. 40.
}

\begin{abstract}
Ensuring the same competition conditions for the companies in EU requires tax harmonization between Member States. In this paper, we review some elements of the harmonization efforts. We will discuss the OECD guidelines on direct taxation and the transfer price regulation as a way to regulate corporate tax optimization behaviour. Based on the Effective Average Tax Rate we introduce the differences in the taxation of profits between Member States. The Common Consolidated Corporate Tax Base is one of the key elements in the harmonization of cross-border corporate profit taxation, so our study has a special focus on the proposal. The undisputed advantage of the CCCTB would be the simplification of the taxation of transactions between Member States. However, it also raises the question of how it limits the ability of each Member State to attract capital and to what extent can assign the profit tax to the given country in proportion to the operation of a company and with this how to realize that the base of the corporate tax focuses on the place of activity.

Keywords: tax competition, tax harmonization, Common Consolidated Corporate Tax Base
\end{abstract}

\section{TAXATION OF CROSS BORDER ACTIVITIES}

National tax systems evolved at the beginning of the $20^{\text {th }}$ century with the rules of economies that are more closed than today. At that time, companies were still typically based in the country where they had official seat and individuals also earned income in their own country, so the application of the 'home state' principle in taxation did not create conflicts between countries. National tax systems did not have to take into account international economic processes, and therefore taxation could only serve domestic governmental purposes. However, as a result of globalization processes, not only trade has become international, but also the transfer and outsourcing of tasks between different countries have become common. Globalization has made the capital market more mobile, which has also entailed corporate profit tax mobility. And the transfer of tax bases between countries gives some countries the opportunity to use their tax policies to create a more favourable tax environment than others to attract capital (Sivák, 2001).

The country's tax differentials play an increasingly important role in determining where companies invest, as some countries offer investors favourable tax conditions in order to create jobs and generate higher budget revenues. 


\section{TAX COMPETITION}

The overall impact of globalization on tax systems has both positive and negative elements. Taxing states are adversely affected by the fact that the free movement of capital offers a new opportunity to minimize the tax payable. At the same time, tax competition encourages countries to reduce taxes on mobile factors of production. Governments remain responsible for carrying out the public tasks of each country, and it is therefore in their fundamental interest to protect the tax base, which is the main revenue source of the budget. In the competition certain companies may enjoy the tax advantages of tax havens (even with zero tax payments) while using domestic public services.

To compensate for the fiscal deficit caused by the decline in tax revenues, public burdens on less mobile factors of production, in particular consumption taxes, will increase, which could lead to distortions in the tax structure. Indeed, in a system which does not favour the formation of internal capital, external resources are likely to be obtained only at the expense of the domestic taxpayer (Balogh, 2004).

The OECD plays a leading role in international action against harmful tax competition. According to its 1998 report (OECD, 1998), tax competition can be harmful if it distorts financial and investment processes, thereby undermining the fairness of tax structures and impairing tax morale.

The problem is also on the agenda of the European Union. At the end of 1997, the Council of the European Union adopted a Code of Conduct for Business Taxation (Council of the European Union, 1998.). According to this paper member states can undertake in their future tax regulations refraining from creating solutions that would allow harmful tax competition and, on the other hand withdrawing their previous rules that provided incentives influencing business establishment in the Union.

The EU Code and the mentioned OECD Guidelines share the same main statements, the main difference between them is that while the Code covers business activities, the general principles of the OECD Directives cover a broader scope. In addition, the OECD typically considers tax havens (close to zero tax measures) harmful, while in the European Union, low (harmful) levels of taxation can be identified relative to an average. In corporate taxation, exceptional preferences are considered unauthorized tools. One way of stopping tax competition may be to properly harmonize national tax systems, which face resistance in several cases.

\section{TAX HARMONIZATION}

National tax policy is an essential tool for the economic policies of the member states, but ensuring the same market conditions in the competition for companies in the European Union requires tax harmonization between member states. Therefore, if necessary, the European Union influences the taxation policy of the member states by tools of tax harmonization, while, if not necessary, it gives room for taxation arising from the sovereignty of the states. The aim of European tax law is to eliminate tax conflicts arising from international relations and differences between national tax 
systems, in favour of completion and functioning of the single market. That is why the European Union is developing common guidelines concerning the member states' tax systems to avoid tax avoidance and double taxation. Tax harmonization in the area of indirect taxation can be said to be adequate, but slow in the area of direct taxation. The most important obstacle is the rule of the requirement of unanimity in the decision making about taxation. The Council in a consultation procedure acting unanimously on a proposal from the Commission shall adopt directives relating to the harmonization of direct and indirect taxation. It is very difficult to reach unanimity on the level of the 28 member states, especially in the case of member states with different levels of economic development. However, the ad hoc decisionmaking and interpretative activities of the European Court of Justice and the nonlegislative bodies of the Union in the form of resolutions in the process of tax harmonization provide some solution. As a result, more and more regulations are adopted, which are non-binding, do not constitute a source of law, have no sanctions, but are still accepted and followed up by member states on a voluntary basis.

Article 2 of the Treaty of Rome contains the requirements which have required harmonization of the laws of the member states of the European Economic Community and sets as objective:

- the establishment of the internal market where the free movement of goods, capital, persons and services is realized

- the establishment of the same competition conditions and the harmonization of national law,

- the establishment of the economic and monetary union.

Tax rules which are obstacles to the free movement of goods and services, income and capital across borders have played an important role among national legislation which inhibit effective operation of the common market.

The objective of tax harmonization is to resolve international tax conflicts arising from the differences and clashes between national tax systems and to harmonize national rules which impede the functioning of the internal market. However, it is not intended to create a federal tax system above the states.

In the process of approximation of European tax laws, member states are facing fierce resistance, as tax law is an element of national fiscal policy sovereignty and such an element of fiscal stability that member states are reluctant to give up.

\section{Directives on direct taxation}

Directives are the main source of positive harmonization. In the field of corporate taxation, the directive on mergers (Council, 1990a), on parent companies and their subsidiaries (Council, 1990b), on arbitration and on taxation applicable to interest and royalty payments (Council of the European Union, 2003) should be highlighted.

In business life the merger or division of businesses is a day-to-day transaction. Most transactions are merely legal changes and the new company will continue its activity as a legal successor. For accounting point of view, it is usually the case that a company with assets with a market value above book value is created. Based on this, the tax rules would prescribe profit tax. In contrast, in many cases, the business would continue its operation and therefore there will not be real capital outflow, so it does 
not seem fair to tax owners on unrealized assets. National rules, in most cases, follow the principle of continuity that transformation does not generate profit tax payment in itself. Interpretation of the situation between member states is very important because, in connection with the common market, there are several cases where transformations (mergers) happen between undertakings in different member states that is why we call the associated directive a merger directive. Its essence is to ensure that, even in the case of mergers of companies from different member states, a tax on profits based on continuity on national level is deferred.

In addition to mergers between companies in different member states, it is often happens that a parent company has a subsidiary in another member state. Obviously, the parent company expects a dividend from the operation of the subsidiary, which it obtains each year. If the parent - subsidiary dividend is paid on national level, the national legislation exempts dividend income from withholding tax. Accordingly, it was also necessary to provide the possibility of tax exemptions for the payment of parent - subsidiary dividends between member states. The purpose of the parent companies and subsidiaries directive is therefore to exempt profit distributions from profit tax and thus to avoid the double taxation of parent companies. According to the directive, a 10 percent ownership stake can already be equated with parent company status.

The directive on the taxation of interest and royalties between associated companies should be applied by Member States since 2005. This means that you must exempt interest and royalty payments from withholding tax between companies with direct or direct shareholdings of at least $25 \%$ in different member states.

\section{TRANSFER PRICING AND TAX OPTIMIZATION}

\section{EU regulation on clearing prices}

International tax law contains a detailed definition of associated companies, whereby companies within a group of companies are considered to be associated if they are able to influence each other's decisions with respect to their ownership structure or function. Due to their related nature, they do not necessarily use the market price in their transactions with each other but, for tax purposes, the optimum price according to tax law. The tax laws of individual countries want to prevent this so-called tax optimization and therefore require associated companies to use so-called usual market price in their transactions with each other namely, the prices that would be used between independent parties in a similar transaction.

Each Member State requires the use of market prices between associated companies and the proof with appropriate documentation, and therefore it may be a significant additional administrative burden for a multinational company to document the applied market prices to the tax authorities of each country. However, the practices of the tax authorities of different member states may differ, so it may happen that one member state accepts the same price while another one does not. As a result, double taxation may occur, so the European Union has set up a Joint Transfer Pricing Training Forum (JTPF), which has been operating informally since 2002 and in institutional form since 2006 to address issues related to transfer pricing. 
Transfer pricing rules require a great deal of group-level information that is not available at individual subsidiaries. Therefore, for subsidiaries, the required information obligation can only be fulfilled through close cooperation with the group and represents a significant administrative burden for multinational enterprises. As a result of the transfer pricing regulation, the proper definition of profit tax base by country has been realized, after that companies' tax burdens are based on the differences in tax reliefs and rates in the member states. Therefore, in the following, we examine how the actual tax burden in Hungary developed between 2008 and 2018.

\section{TAXATION OF CORPORATE PROFITS IN THE EU}

Profit tax revenues vary across EU member states, due to differences in tax base definition and tax rates. Figure 1 below shows that in the most (mainly Central and Eastern European) member states the profit tax revenue as a share of the GDP is much below the EU average.

Figure 1

\section{Corporate profit tax revenue as a proportion of GDP (2018)}

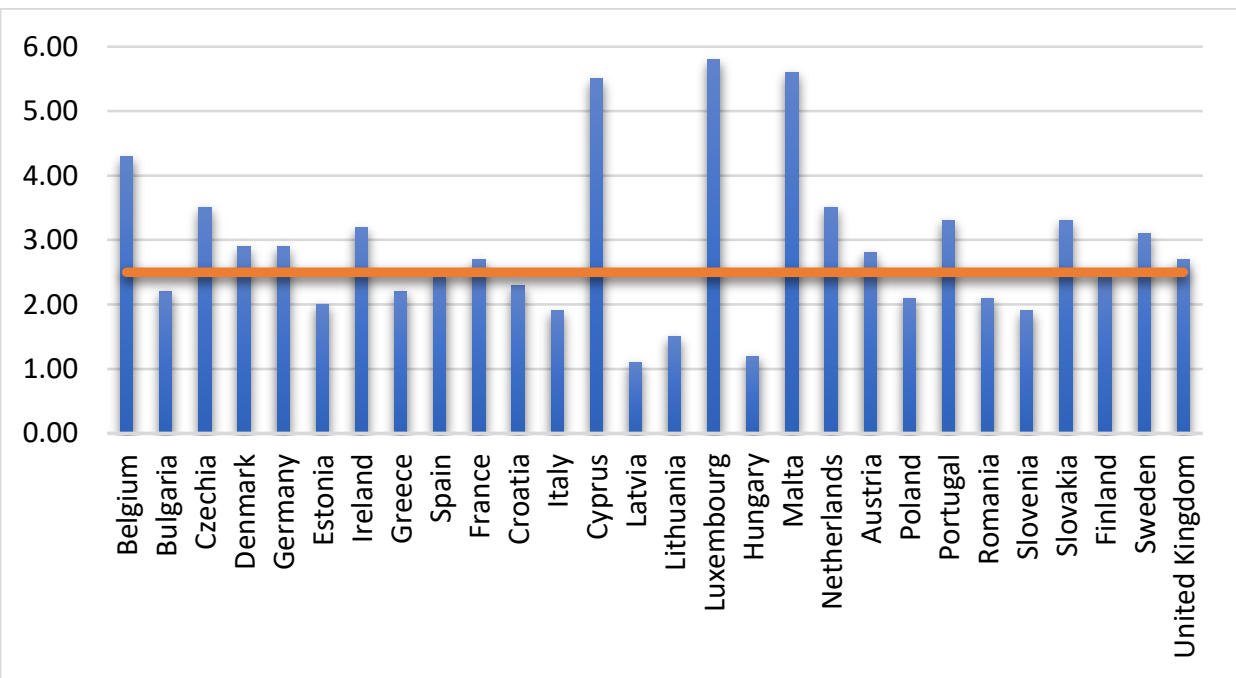

Source: Based on Eurostat (2019)

In Europe, the weighted average corporate tax rate has been steadily declining, while in the 1980s it was 38.8 percent, today the corporate tax burden on corporate profits has fallen to an average of 22.5 percent (Asen, 2019). Organizations operating in Hungary have had to pay an even lower $9 \%$ corporate profit tax since 2017 , which is the lowest value in the EU member states (Figure 2).

The main reason for the general corporate tax rate reduction trend is the strengthening of the states' ability to compete and attract capital. Thanks to the development of technology and as an effect of globalization investors has become 
much more flexible, so the composition of their corporate tax base and tax reliefs and the level of tax rates in a given country are a key consideration when investing.

Figure 2

\section{The corporate tax rates in Europe 2018}

\section{Corporate Income Tax Rates in Europe \\ Combined Statutory Corporate Income Tax Rates for 2018}

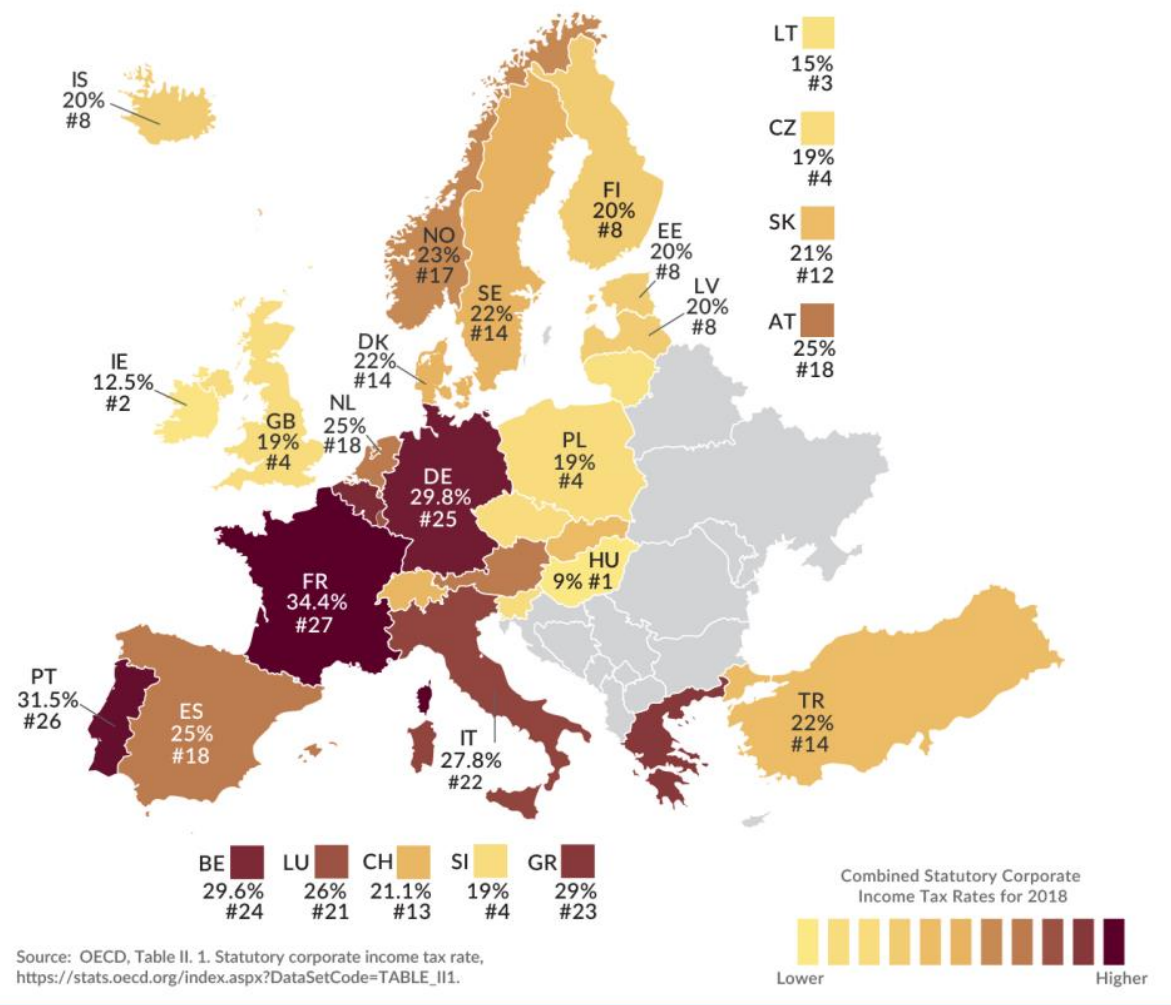

TAX FOUNDATION

Source: https:// files.taxfoundation.org/20190206165815/FINAL.png

Each year, the European Economic Research Center publishes the effective tax rate for each EU member state. The effective tax rate is defined by the method of Devereux and Griffith. In essence, the method describes how big the profit tax will be in a given country for a putative investment (Hajdu, 2012). In addition to corporation tax, all tax liabilities that are based on corporate profits are included in the calculation. For example, in Hungary, in addition to the $9 \%$ corporate tax, there is a $2 \%$ local business tax and a $0.3 \%$ innovation contribution.

The tax burden in the EU-28 has not changed significantly in recent years. In each examined years, the lowest tax burden was assumed for Bulgaria each year, 10\% as it can be seen in Figure 3 as well. 
Figure 3

Trends in the corporate tax burden in EU Member States (2008-2018)

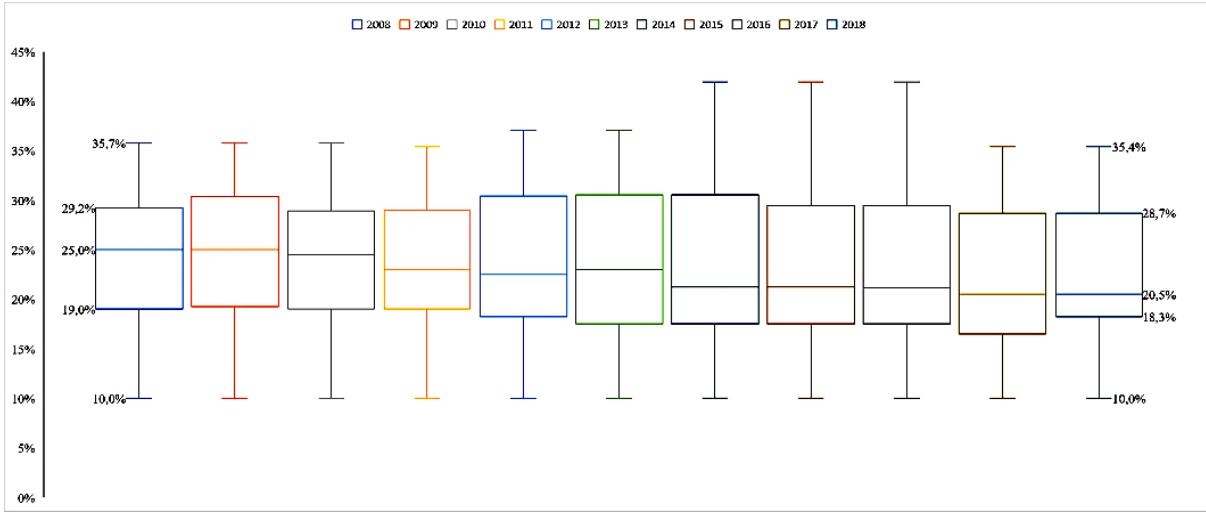

Source: Based on ZEW (2018)

It can be seen that the standard deviation of the data was the highest in the period 20142016, due to the increase of the tax burden in France to nearly 42\% in the period 20142016. The increase was caused by the increase of the special corporation tax from $8.3 \%$ to $14 \%$. Since 2017, this special tax has been reduced by the French government to $3.3 \%$, so the tax burden has also decreased to $35.4 \%$. Nevertheless, companies still have to pay the highest tax burden in France (among EU member states). On data of the boxplot it can be seen that the median of the tax burden shows a significant decrease. While the average tax burden declined by 1.4 percentage points over the 10-year period (from $23.62 \%$ to $22.22 \%$ ), the median reduced by 4.5 percentage points. This suggests that more and more member states have begun to reduce their corporate profit tax rates (Figure 4).

\section{Figure 4}

\section{Change in corporate tax burden from 2008 to 2018 ( $\%$ points)}

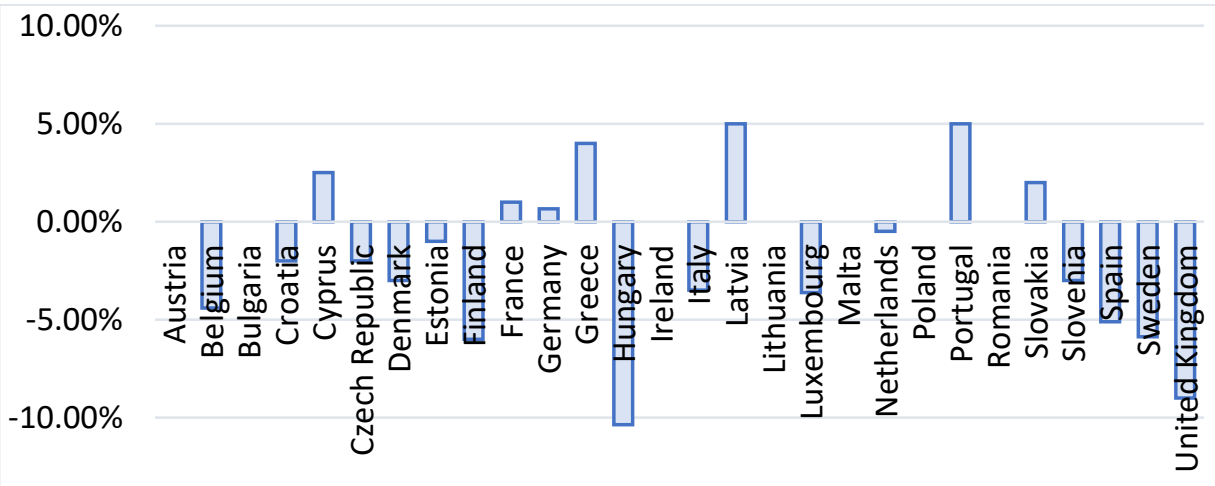

$-15.00 \%$

Source: Based on ZEW (2018) 
Out of the EU28 countries, corporate tax burden increased in 9 member states (Cyprus, France, Greece, Latvia, Portugal and Slovakia), remained unchanged in 7 member states (Austria, Bulgaria, Ireland, Lithuania, Malta, Poland and Romania) and decreased in 12 member states. The most significant decrease can be seen in Hungary, as it decreased from $22.44 \%$ in 2008 to $11.09 \%$ due to the reduction of the corporate tax rate and the elimination of the special tax.

In order to eliminate tax competition from different tax burdens and administrative burdens related to transfer pricing, there has been ongoing discussion in the European Union for several years on the definition of a common consolidated corporate tax base.

\section{THE COMMON CONSOLIDATED CORPORATE TAX BASE AS AN INSTRUMENT OF TAX HARMONIZATION}

Common Consolidated Corporate Tax Base (CCCTB) first emerged in 2001 and as a result of several years of work, on March 16, 2011 (Commission of the European Communities, 2001), the European Commission submitted a proposal for a directive on an EU level calculation of Common Consolidated Corporate Tax Base (European Commission, 2019). According to this, on one hand the calculation of the tax base would happen in the same way in every country, so it would be "common". on the other hand, the tax base of each member of that group of companies would be calculated together (consolidated) and then the tax base would be allocated to each member state according to certain rules. Member states would levy their tax rates on the tax base to which they are assigned. Illustrating on an example, businesses operating in several countries would calculate their tax base according to one rule. The tax base calculated on European level would be allocated to certain countries according to certain specific criteria (such as the turnover of the business, the value of the assets, the wage costs), and then the tax base calculated in the above mentioned way would be taxed at the country's own tax rate. This system is very similar to the US tax system, where businesses share their tax base in similar ways across the states. However, the difference is that in the US there is a federal tax system and a tax as well, so a common tax base is needed.

The new corporate tax system:

- will be obligatory for large multinational groups, but companies with revenues of more than EUR 750 million per year globally will be taxed at the actual place where their profits are generated;

- will close the loopholes currently associated with the profit reallocation from tax reasons;

- will encourage companies to finance their activities by raising equity and exploiting market opportunities instead of borrowing;

- will support innovation through tax incentives for R\&D related to real economic activity.

The CCCTB does not regulate the rate of corporate tax, as this area remains a member state competence. It creates, however, a more transparent, efficient and fair system for calculating the tax base for cross-border businesses, which will radically reform corporate taxation across the EU (European Commission, 2016a). 
Businesses will now need to apply a single regulatory system and submit a single tax return to their national tax authorities for all their EU activities. The CCCTB is expected to reduce its regulatory compliance time by $8 \%$ annually and by up to $67 \%$ to set up a subsidiary, so businesses can start their foreign activities easily (European Commission, 2016b).

The CCCTB also contributes to the wider objectives of improving growth, employment and investment and is expected to increase the total amount of investment in the European Union by up to $3.4 \%$.

Its important advantage is that companies can include their profits in one member state and their losses in another one in their tax base, thereby avoiding double taxation.

The CCCTB bridges aggressive tax planning and eliminates transfer pricing which are the main tools of tax evasion. The harmonization would have clear advantages for companies active in the EU, but on the other hand, a lot of member states fears for its fiscal autonomy. The introduction of the CCCTB requires the consent of all member states, which, however, is still uncertain due to the fragmentation of member states. According to the Commission, this arrangement may also be introduced in the context of enhanced cooperation, which requires the consent of at least nine member states, in accordance with existing EU legislation.

\section{Its essence, methodology}

Before examining the operation of the CCCTB, we introduce how companies determine their corporate tax base. Currently, a multinational company-group with subsidiaries in several member states has to determine their tax base individually and submit their tax returns on the basis of the national rules of that member state. Each tax return contains the information determined on the basis of the results of that subsidiary. The corporate tax base is determined on the basis of the profit before tax according to the Hungarian regulation (Act LXXXI of 19961). The profit before tax has to be modified by various tax base corrections. The tax base adjustments result in the tax base of the business. $9 \%$ of the tax base is payable in Hungary as corporate tax. In the current system, if a multinational company makes a loss in one member state while its other company is profitable, the profitable member company will have to pay tax because the profit cannot be consolidated with the loss-making member's loss. The introduction of the CCCTB would change this by consolidating the tax base of the member companies, i.e. a loss in one member state would reduce the profits generated by a subsidiary in another member state. According to the plan, the group would submit a consolidated corporate tax return that includes the tax base, corporate tax and all other necessary information for all of its member companies. The CCCTB does not deal with the issue of tax benefits, so theoretically the corporation tax on a given subsidiary, as defined above, could be reduced by the tax relief offered by the member state.

Following the consolidated determination of the corporate tax base, the multinational company distributes the CCCTB among its subsidiaries on the basis of

\footnotetext{
1 https:// net.jogtar.hu/jogszabaly?docid=99600081.tv
} 
a sharing formula. The theoretical background of the sharing formula is the ratio of economic presence in the member state. The economic presence is proposed to be characterized by the following factors: number of employees, cost of labour, value of assets, revenue. From the CCCTB rules, the sharing formula is the most controversial issue among member states. This is because, depending on the sharing formula, member states' corporate tax revenues may decrease or increase compared with current ratios and tax competition could increase.

All wages and salaries paid to the employee (wages, dividend, bonuses, etc.) must be taken into account in the wage bill. The problem is that wage levels vary significantly across the Union, so without weighting the wage level in the member states there is a risk that where labour force is cheaper, there the share of tax base would be unreasonably little.

The valuation of assets raises additional questions, as it does not matter whether it is necessary to consider them at market value, at total cost or at accounting value. However, the valuation of intangible assets is very difficult, these are highly mobile, so they can be easily used as part of a formula for profit-sharing. In addition, it is an important question whether we consider leased assets to be included or not, which can also provide tax planning (leasing instead of purchasing assets).

In connection with revenue, a distinction should be made between reckoning at the place of origin and arrival. In the case of accounting at the place of origin, revenue is taken into account at the place of dispatch of the goods, in the case of accounting at the place of arrival, revenue is generated where the goods are put on the market. Origin accounting may give rise to a profit shift (it is up to the enterprise to decide where to dispatch the goods).

Besides the factors, the weighting of the individual factors in the formula is an important issue. Sharing is possible based on the so-called Massachusetts formula with equal weights (used by most US states in the 1950s) or with different weights (in recent years in the USA revenue is represented by different weights in the formula, in 200423 states used a formula where the share of the wage and property was $25 \%$ and the income's one was $50 \%$; according to the Canada-formula the share of the revenue and the wage was $50-50 \%$ ).

On the basis of the sharing formula, the Commission envisages that the tax base of company A may be determined as follows.

$$
\frac{1}{\mathrm{~m}} * \frac{\text { Rev }^{\mathrm{A}}}{\operatorname{Rev}^{\text {Group }}}+\frac{1}{\mathrm{n}}\left[\frac{1}{2} * \frac{\text { Wage cost }^{\mathrm{A}}}{\text { Wage cost }^{\text {Group }}}+\frac{1}{2} * \frac{\text { Numb.emp }^{\mathrm{A}}}{\text { Numb.emp }^{\text {Group }}}\right]+\frac{1}{\mathrm{o}} * \frac{\text { Asset value }^{\mathrm{A}}}{\text { Asset value }^{\text {Group }}}
$$

where: $\mathrm{m}+\mathrm{n}+\mathrm{o}=1$

In the sharing formula, numerators include company A's sales revenue, wage cost, number of employees and asset value. The formula compares this data to the data defined on the group level. The sharing formula weighs the three factors, but the exact extent of the weights has not been decided yet. Here is an example to illustrate the formula.

A company-group consists of A and B companies. Company A is a company registered in Hungary, company B is in Germany. A is only active in Hungary and B is exclusively active in Germany. The results are summed up in Table 1. 


\section{Table 1}

\section{The sharing formula in practice}

\begin{tabular}{|l|c|c|c|}
\hline & $\begin{array}{c}\text { Company A } \\
\text { Hungary }\end{array}$ & $\begin{array}{c}\text { Company B } \\
\text { Germany }\end{array}$ & Group \\
\hline Revenue & 100 & 200 & 300 \\
\hline wage costs + number of employees & 50 & 150 & 200 \\
\hline Asset value & 100 & 250 & 350 \\
\hline Proportion of the tax base per country & $28,97 \%$ & $71,03 \%$ & \\
\hline
\end{tabular}

Based on the sharing formula, 28.97\% of the Common Consolidated Tax Base is allocated to Hungary and $71.03 \%$ to Germany.

\section{CONCLUSION}

National tax policy is an essential tool for the economic policies of the member states, but ensuring the same conditions in the market competition for companies in the European Union requires tax harmonization between member states. One of the most important elements of the harmonization efforts is the introduction of transfer pricing regulation in the field of profit taxation, which has helped to reduce aggressive tax planning slightly between countries. However, transfer pricing documentation is a significant administrative burden for businesses. In the long term, the EU's aims are to create a harmonized profit tax system, the first step in which member states should agree to establish a so-called common consolidated corporate tax base. The conciliation process has not reached the necessary agreement so far, so we can only evaluate the proposal with models built on the vision methodology. An indisputable advantage of the CCCTB would be the lower corporate administrative burden and the definition of taxation between member states. However, there are several concerns about the common tax base. One of the arguments against is the Central and Eastern European countries' one, as in these countries wide range of investment tax base and tax incentives can be applied. All of these would appear as a capital attractive fiscal policy instrument in national taxation, but opponents believe it would be deprived in the case of the introduction of a common corporate tax base on European level. Nevertheless, if we look at the relationship between the EATR and FDI on Figure 5, we can see that the inflow of foreign capital into Hungary increased significantly between 2008 and 2016, when the tax burden was nearly constant. However, with the significant decline in 2017, FDI showed no increase.

All of these are obviously not surprising, since the FDI is influenced by several other economic/legal factors besides the tax burden on profits. On the other hand, the reduction of the tax burden has a long-term effect, so we cannot draw accurate conclusions over a year.

Another disadvantage of the CCCTB is that its application would be restricted to EU member states. However, most multinational companies also have significant activities outside the EU, which would not be required to determine a common tax 
base. To illustrate this, it is worth examining Wizz Air Hungary Kft's profit taxation and the country-specific interest of its operations. Wizz Air Hungary Aviation Limited Liability Company provides scheduled air passenger services within Europe and to the Middle East. The annual report includes the data of the Hungarian company and its branches (in Poland, in Bulgaria, in Switzerland, in Romania, in the Czech Republic, in Serbia, in Lithuania, in Macedonia, in Latvia, in Slovakia, in Georgia, in Ukraine, in the UK, in Greece, in Austria and in Cyprus) but this is not a consolidated report because branches are not legally distinct companies. From a tax point of view, it is important to underline that aviation-related activities are taxable under Article 8 of the OECD Model Convention in the state where the company has its place of effective management. In the case of Wizz Air Hungary Kft., the central management has been carried out in Switzerland since 1 April 2010. Accordingly, Switzerland is entitled to tax the profits of the enterprise.

\section{Figure 5}

\section{The corporate tax burden and FDI in Hungary}

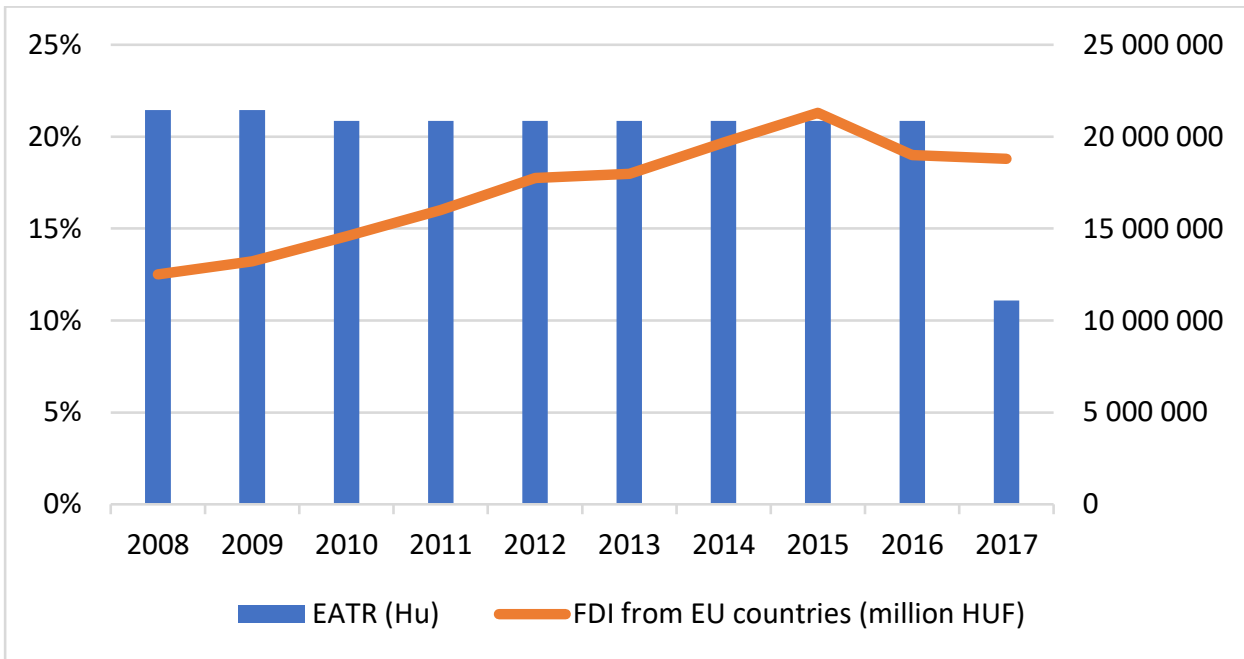

Source: Source: Based on ZEW (2018) and MNB (2019)

The company's after-tax profit for 2018 was EUR 261,155 thousand, of which almost every branch has a negative after-tax profit (Figure O). A total of EUR 364,016 thousand in after-tax profits can be attributed to the headquarters, which in this case is Budapest. Therefore, from corporate profit tax's point of view of, it can be concluded that the highest income can be tied to the headquarters, however, according to the OECD directive, not Hungary but Switzerland is entitled to profit taxation and the Hungarian budget loses significant tax revenue. All of this underlines the disadvantage of maintaining other provisions of the OECD Model Convention (in this case, taxation of sea and inland shipping and air traffic) and extending it to EU member states during examining the introduction of the CCCTB. 
Figure 6

The share of the individual branches in the after-tax profit of Wizz Air Hungary Kft

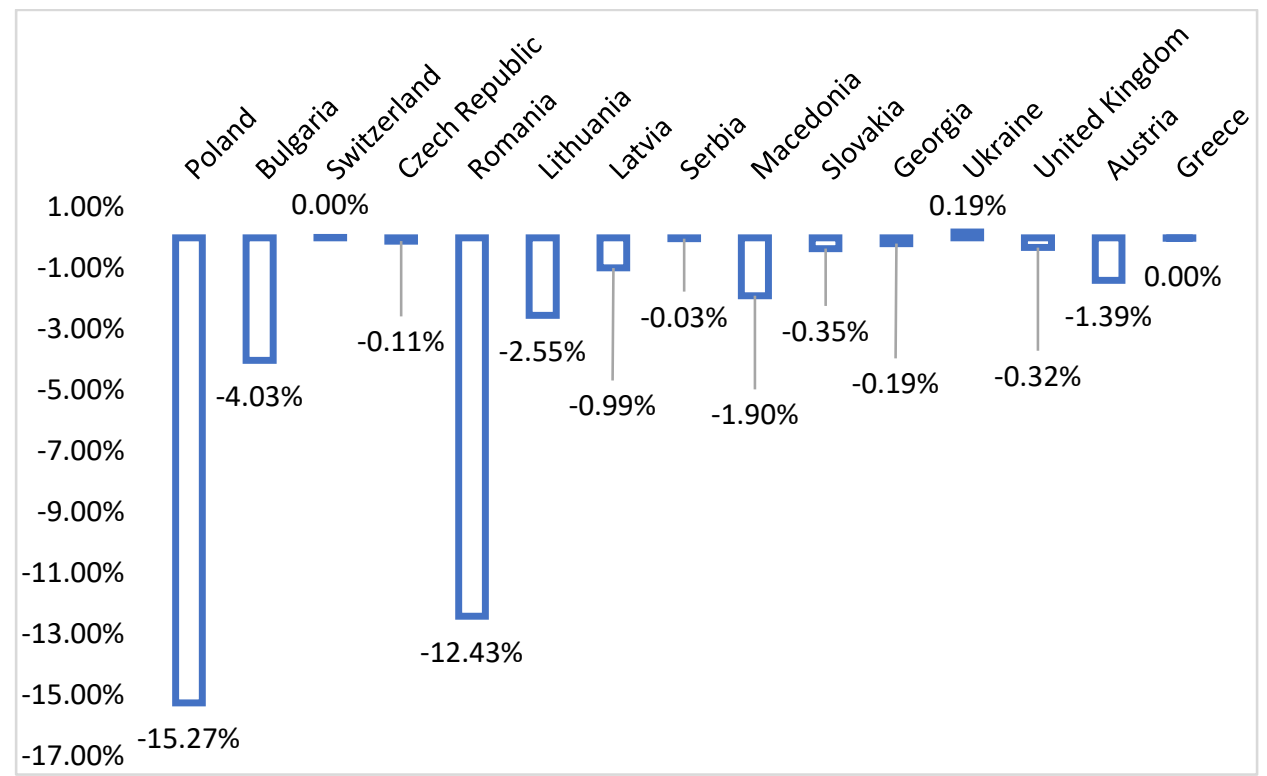

Source: Based on Wizz. Air Hungary Kft. (2018)

\section{REFERENCES}

Asen, E. (2019): Corporate Income Tax Rates in Europe. [online]<URL: https://taxfoundation.org/corporate-tax-rates-europe-2019/>

Balogh, L. (2004): Döntsd a tőkét? (in Hung.) In: Hitelintézeti Szemle, 3. 5. 22-37. p. Commission of the European Communities (2001): Communication from the Commission to the Counil, the European Parliament and the Economic and Social Committee; Towards an Internal Market without tax obstacles; A Strategy for Providing Companies with a Consolidated Corporate Tax Base for their EUwide activities. [online] <URL: https://eur-

lex.europa.eu/LexUriServ/LexUriServ.do?uri=COM:2001:0582:FIN:EN:PDF>

Council (1990a): Council Directive 90/434/EEC of 23 July 1990 on the common system of taxation applicable to mergers, divisions, transfers of assets and exchanges of shares concerning companies of different Member States. In: Official Journal L 225, 20/08/1990 1-5 p. [online] <URL: https://eur-lex.europa.eu/legalcontent/EN/TXT/HTML/?uri=CELEX:31990L0434\&from=EN>

Council (1990b): Council Directive 90/435/EEC of 23 July 1990 on the common system of taxation applicable in the case of parent companies and subsidiaries of different Member States. In: Official Journal L 225, 20/08/1990 6-9 p. [online] <URL: https://eur-lex.europa.eu/legal-content/EN/TXT/HTML/?uri=CELEX: 31990L0435\&from $=\mathrm{EN}>$ 
Council of the European Union (1998): Conclusions of the ECOFIN Council meeting on 1 December 1997 concerning taxation policy. In: Official Journal C 002, 06/01/1998 1-6 p. [online] <URL: https://eur-lex.europa.eu/legalcontent/EN/TXT/HTML/?uri=CELEX:31998Y0106(01)\&from=EN $>$

Council of the European Union (2003): Council Directive 2003/49/EC of 3 June 2003 on a common system of taxation applicable to interest and royalty payments made between associated companies of different Member States. In: Official Journal L 157, 26/06/2003 49-54 p. [online] <URL: https://eurlex.europa.eu/legal-content/EN/TXT/HTML/?uri=CELEX:32003L0049\& from $=\mathrm{EN}>$

European Commission (2016a): Corporate Tax Reform. [online] <URL: https://ec. europa.eu/taxation_customs/sites/taxation/files/ctr_factsheet2016.pdf $>$

European Commission (2016b): Commission proposes major corporate tax reform for the E. [online] <URL: https://ec.europa.eu/commission/presscorner/ detail/en/IP_16_3471>

European Commission (2019): Common Consolidated Corporate Tax Base. [online] <URL: https://ec.europa.eu/taxation_customs/business/company-tax/commonconsolidated-corporate-tax-base-ccctb_en>

Eurostat (2019): Taxation in 2018 Tax-to-GDP ratio up to $40.3 \%$ in EU. [online] <URL: https://ec.europa.eu/eurostat/documents/2995521/10190755/230102019-AP-EN.pdf/68739572-f06a-51e4-3a5b-86e660a23376>

Hajdu, E (2012): A tényleges társasági adóterhelés mérése és trendje az Európai Unióban. (in Hung.) In: Gazdaság és Társadalom 2012. különszám, 132-156 p. doi: $10.21637 /$ gt.2012.00.08.

MNB (2019): BPM6 módszertan szerinti adatok (in Hung.) [online] <URL: https://www.mnb.hu/statisztika/statisztikai-adatok-informaciok/adatokidosorok/viii-fizetesi-merleg-kozvetlen-tokebefektetesek-kulfolddel-szembeniallomanyok/kozvetlentoke-befektetesek/bpm6-modszertan-szerinti-adatok>

OECD (1998): Harmful Tax Competition. An Emerging Global Issue. 84. p. Paris: OECD Publishing, ISBN: 9789264162945 doi: 10.1787/9789264162945-en

Sivák, J. (2001): A globalizáció árnyoldala - a káros adóverseny. (in Hung.) In: Pénzügyi Szemle 5. 397-406. p.

Wizz Air Hungary Kft. (2018): Annual Report 2018. [online] <URL: https://wizzair.com/static/docs/default-source/downloadable-

documents/corporate-website-transfer-documents / annual-

reports/wizz_air_holdings_plc_annual_report_and_accounts_2018_3a126a45. $\mathrm{pdf}>$

ZEW (2018): Project for the EU Commission TAXUD/2018/DE/307. Intermediary Report 2018. Effective Tax Level. Using the Devereux/Griffith Methodology. [online] <URL:

https://ec.europa.eu/taxation_customs/sites/taxation/files/final_report_201 8_effective_tax_levels_revised_en.pdf $>$ 
Correspondent author:

\section{Diána KOPONICSNÉ GYÖRKE}

Kaposvár University

Faculty of Economic Science

H-7400 Kaposvár, Guba Sándor u. 40.

e-mail: gyorke.diana@ke.hu 